\title{
Surface Treatment Technologies for Wear Resistance Increasing of 42CrMo4 Steel
}

Van Thanh Doan, David Kusmic, Miroslav Pospichal

Faculty Of Military Technology, University of Defence in Brno, Kounicova 65, 66210 Brno, Czech Republic. E-mail: thanhvan.doan@unob.cz,david.kusmic@unob.cz,miroslav.pospichal@unob.cz

The present study was directed to investigate the mechanical and tribological properties of $42 \mathrm{CrMo4}$ (CSN 41 5142.3) steel, which was thermochemical treated by the technologies of tenifer, manganese phosphate and plasma nitriding combining with blackening. Plasma nitriding was carried out for the samples under different condition of gas mixture under temperature of $480^{\circ} \mathrm{C}$ (plasma sputtering) and $500^{\circ} \mathrm{C}$ (plasma nitriding process) for $10 \mathrm{~h}$. Besides determining the microhardness (HV 0.05), surface hardness, and microstructure, this paper also concentrates on the field of wear resistance evaluation and friction coefficient of these surface treatments. Based on "ball on flat" test, calotest, and profile observation, it was found that tenifer technology is suitable to increase the wear resistance, and manganese phosphate improves clearly not only wear resistance but also friction coefficient, which can be usable for weapon production.

Keywords: Wear resistance, Friction coefficient, Plasma nitriding, Tenifer, Manganese Phosphate

\section{Acknowledgement}

The paper was prepared with the support of the Project for the Development of the Organization and by the Specific research project 2014 of the Department of Mechanical Engineering, UoD "Promoting Research, Science and Inovation in the Field of Engineering".

\section{References}

[1] SUCHANEK, J., KUKLÍK, V., ZDRAVECKÁ, E. (2007). Abrazivní opotřebení materiálů. České vysoké učení technické, Praha, ISBN 978-80-01-03659-4.

[2] HUTCHINGS, I. New directions in tribology: plenary and invited papers from the First World Tribology Congress 8-12 September 1997: organised by the Tribology Group of the Institution of Mechanical Engineers (IMechE). Bury St Edmunds: Published by Mechanical Engineering Publications for the Institution of Mechanical Engineers 1997, 500 p. ISBN 1860580998.

[3] BEČKA, J. (1997), Tribologie. Vyd. 1, Vydavatelství ČVUT, Praha, ISBN 8001016218.

[4] POPELÍNSKÝ, LUBOMÍR. Československé automatické zbraně a jejich tvůrci. Vyd. 1. Praha: Naše vojsko, 1999, 198 p. ISBN 8020605673.

[5] LUGS, Jaroslav. Ruční palné zbraně: soustavný přehled ručních palných zbraní a dějin jejich výroby. Praha: Svojtka \& Co., 2003, 412 p. ISBN 8072376640.

[6] HRUBY, V. (2007). Nová technologie úpravy hlavních součástí pistolí: Navržena v rámci řešení výzkumného záměru FVT 0000404 Výzkum a vývoj moderních materiálů a technologií pro aplikace u vojenské techniky. Univerzita Obrany, Brno.

[7] HRUBY, V., HOLEMAR, A. (1991). Katalog technologických listů iontové nitridace. Brno, STROJTECH.

[8] DOBROCKY, D., KUSMIC D. (2015). The effect of plasma nitriding process on the change of dynamic parameters of steeel DIN 1654/4. In: Manufacturing technology, Vol. 15, pp. 14-20. ISSN 1213-2489.

[9] KUSMIČ, D., DOBROCKÝ, D. (2015). Corrosion Resistance of Plasma Nitrided Structural Steels. In: Manufacturing Technology, 2015, Vol. 15, No. 1, pp. 64-69. ISSN 1213-2489.

[10] HOLEMAR, A., HRUBY, V. (1989). Iontová nitridace v praxi. 1. vyd. Státní nakladatelství technické literatury, Praha. ISBN 80-03-00001-7.

[11] SOLA, R., POLI, G., VERONESI, P., GIOVANARDI, R. (2014). Effects of Surface Morphology on the Wear and Corrosion Resistance of Post-Treated Nitrided and Nitrocarburized 42CrMo4 Steel. In: Metallurgical and Materials Transactions. ISSN 1073-5623.

[12] AUTAY, R., KCHAOU, M., DAMMAK, F. (2015). Friction and wear behaviour of induction hardened ISO $42 \mathrm{CrMo} 4$ low-alloy steel under reciprocating sliding conditions. In: Proceedings of the Institution of Mechanical Engineers, Part J: Journal of Engineering Tribology, pp. 115-125. DOI: 10.1177/1350650114544201. ISSN 1350650 . 
[13] SURZHENKOV, A., ADOBERG, E., PODRA P., SERGEJEV, F., MERE, A. (2013). Impact and Sliding Wear Properties of Single Layer, Multilayer and Nanocomposite Physical Vapour Deposited (PVD) Coatings on the Plasma Nitrided Low-Alloy 42CrMo4 Steel. In: Engineering Materials and Tribology. ISSN 1013-9826.

[14] Pelagić, Z., Nágel’, M., Žmindák, M., Riecky, D. (2015). Wear Simulation Modeling by Using the Finite Element Method. In: Manufacturing technology, Vol. 15, No. 2, pp. 191-195. ISSN 1213-2489.

[15] BAKALOVA, T., LOUDA, P., VOLESKÝ, L., ANDRŠOVÁ, Z. (2014). The Use of Optical Microscopy to Evaluate the Tribological Properties. In: Manufacturing Technology, 2014, Vol. 14, No. 2, pp. 256-261. ISSN $1213-$ 2489.

[16] PYE, D. (2003). Practical nitriding and ferritic nitrocarburizing. 2nd edition, In: ASM International Materials, Park 2003, pp. 66-68.

Paper number: M201553

Copyright (C) 2015. Published by Manufacturing Technology. All rights reserved. 